\title{
Reflection and Thought on Peasant Paintings in Longmen of Guangdong
}

\author{
Shaomin Chen \\ Guangdong Polytechnic of Industry and Commerce \\ Guangzhou, China
}

\begin{abstract}
Peasant paintings is a kind of folk art, yet it has unique characteristics compared to traditional folk art. Though appeared in the modern society, peasant paintings has a thick historic deposition in China, it originated from the folk, yet differing from general traditional folk art, it was birthed for politics and developed relying on the governmental support, and it got its name due to the identity of creators, after the 1980s, peasant paintings are generally called modern folk painting. Just for the reasons, the development courses of peasant paintingss at 60-70 villages are almost the same across the country. Though styles of peasant paintings vary with regions, yet the development courses and problems they are similar to some degree.
\end{abstract}

Keywords-Peasant paintings in Longmen; Guangfu culture; Hakka culture

\section{INTRODUCTION}

Longmen County, Huizhou, Guangdong is a place where Guangfu culture and Hakka culture meet together, it has local Yaozu culture with unique characteristics. Peasant paintings at Longmen started in the 1970s, which took political slogans, local folk culture, life and labor as themes, seeking for the position of its, gradually it becomes a local cultural brand.

\section{DEVELOPMENT COURSE OF PEASANT PAINTINGS AT LONGMEN, GUANGDONG}

The earliest time of Chinese peasant paintings to appear was in the 1950s when the wall painting was in a hot wave in the period of great leap forward. Actually real peasant paintingss appeared in the 1970s, just like other peasant paintingss in the country, the peasant paintingss at Longmen, Huizhou, Guangdong Province just came from the special time.

At that time, the front of fines arts were advocating to fully support and assist workers, farmers and soldiers for creation in spare time, and a hot ware came with worker painting, peasant paintings and soldier painting around the country. The peasant paintingss made by farmers from Huxian County, Shaanxi became models for peasant paintings, which brought a long influence in the country, it was true that the peasant paintingss at Longmen were also influenced, on which, a deep impression of the time can be found. Just like what are shown in the Discussion on Chinese Peasant paintingss written by Zuo Hanzhong, "Most of the works are going toward realism in styles, and the expression of beauty in form meets the needs of political contents, the strength of folk styles are abandoned and they have to should heavy loads in technique" 2 .

In the late 1970s, peasant paintingss at Jinshan took the lead to get rid of thick political contents, turning to daily life, whose higher decoration attracted eyeballs of the field of fine arts, becoming the first of that time. From then on, farmer paints at Longmen started to borrow languages and technique of expression of traditional folk art at home, which went off the way "cooperate with the central work for propaganda" and responding to "double hundred and double serve" guideline in art in the 1970s, starting to create works aiming at local customs and traditional folk art.

In order to explore local styles at Longmen, in the late 1980 s and the early 1990s, painters launched an attempt "Pursue Southern Culture Styles". Soon in order to meet the needs of some clients from Hong Kong, they started to create colorful painting, hilarious folk painting and so on, which have last till now.

The over 30-year development course of peasant paintingss at Longmen is just the reduction of most of peasant paintingss development at home. Up to now, the peasant paintingss at Jinshan and Huxian County have brought favorable economic benefits, and peasant paintingss have become means for local governments to develop rural industrial culture and characteristic economy, and the development of peasant paintingss and construction of peasant paintings villages have taken on a promising trend. Similarly the peasant paintingss at Longmen also have to meet the market, after years of hard work, we have seen its potentials for further development and some problems that should be regarded and considered.

\section{EXPLORING REGIONAL STYLES}

Peasant paintings is not created freely instead it has been closely related to local customs and practices, morals and customs, especially the local folk art styles, which are regional styles shown in peasant paintingss.

Wu Tongzhang, instructor of peasant paintings at Jinshan thinks, local features cannot be fabricated, which shall be developed on the basis of traditional local folk art. Longmen, Guangdong Province, belongs to villages of Lingnan Mountain areas, which has no unique folk art. In the 1980s, influenced by successful experience at Jinshan, farmer painters at Longmen started to borrow folk art with diverse styles at home, therefore, seen from the sources, the peasant paintings at Longmen has no 
rich soils of traditional art like that in other regions, which is an imperfection inherent for its development. Afterwards, farmer painters started to dig local Yaozu culture, in pursuit of southern styles, for example, a great number of Lingnan fruit designs, as well as some works showing traditional festivals of Yaozu people, were adopted on characters as decoration. The attempt didn't last too long, which was not mature either. After all, the local Yaozu culture at Longmen was Chinesized earlier, and the original colors of ethnic groups had disappeared, and the so called southern culture was just surmised by farmer painters.

However, this attempt was also helpful, some commonly used technique of expression and decorative symbols were remained and properly used in later works, which could be taken as basic characteristics of Longmen feature. Yet seen as a whole, the overall style position of peasant paintings at Longmen is a little unclear, and regional characteristics are not clearly shown, so it still needs the joint efforts of local farmer painters and peasant paintings instructors. Shengsi, Zhejiang Province is a fishing island, similar to Longmen, having no foundation for folk art, and the folk customs have no unique features either, yet the fisherman painting at Shengsi has strong tastes of original art and thick and unique styles of fishing villages with a high level in art, which can be borrowed for farmer painters at Longmen.

It needs to form characters of our own within styles of groups, so do farmer painters at Longmen. In addition to inheritance, farmer painters will influence and simulate each other while learning, and the dependence on generality is stronger than exploring personality, similar or even the same painting styles are obvious, which however will do bad to the development of painters and the groups.

Nowadays, the washing of commercial waves has rubbed down edges and angles of peasant paintings, in some regions, peasant paintings have become so smooth and bright, sweet and vulgar but in lack of personalities and vague in appearance. Lack of personalities means loss of value to continue, to which each farmer painter should pay more attention.

\section{PRICES FOR PURSUIT OF BENEFITS}

Peasant paintings has considerate potential benefits, which has been proved by the practices at Huxian County and Jinshan, etc.

It is true that the benefits are attractive, yet it also need high prices to get the benefits, so it has to been considered carefully.

As a special form of folk art, the existence and development of peasant paintings just needs financial support the same as other folk art, yet it is just the lack of this point which has caused many folk culture are at the risk of disappearance in the country, besides, due to the urgent needs of rural economy, peasant paintings is introduced to markets, however, farmer painters have to face the dilemma: insist on the traditional way to go or go to complete in markets. Ultimately the market is what they need, for benefits are what they want. However, while bringing profits, peasant paintings has its core nature changed.
Currently the peasant paintings at Longmen is still at the beginning stage, local cultural departments raised a thought of "walking by two legs": on one hand, protect quality products and original; on the other hand, develop completely in markets. It looks a good policy, which at least aims to keep the nature of peasant paintings in any cases, actually it is to control the market-oriented progress, yet no one knows how long it can last.

Suppose there are top end and low end markets for peasant paintingss, then the original quality paintings will enter the top end markets, whose art value shall be acknowledged, of course they will have an ideal price, after all the market share is limited, more peasant paintingss will go to the low end markets, where peasant paintingss are distorted with low prices, low quality and rough making.

If work of art becomes cheap products pouring into markets, hundreds and thousands of farmer painters who work hard in painting become low-price laborers. If the prices are very low, they have to increase the amount, improve the efficiency, produce in batches, start flow process and simplify procedures, the peasant paintingss which should be work or art have turned to semi-industrial products, which have lost almost all of its nature as work of art. The phenomena can be seen in the peasant paintingss markets at Jinshan and Huxian County, which maybe meet the needs of some consumers but ruin the images of their own.

Do peasant paintingss have to be introduced to markets, Could a balanced point be not found between commercial benefits and work of art?

No one knows the peasant paintingss at Longmen will follow the same way in the future.

\section{CONCLUSION}

The development of peasant paintingss always face dilemma, maybe it is still a new thing or it is extremely special. To solve the dilemma still needs borrowing and practices, the peasant paintingss at Longmen are expected to find a proper position and a scientific way for development.

\section{REFERENCES}

[1] Wu Dongzhang, Artistic Characteristics of Peasant paintingss at Jinshan on Research of Chinese Fine Arts, Guizhou Fine Arts Publishing House, Version in 1987.

[2] Zuo Hanzhong, Li Xiaoshan, Discussion on Peasant paintingss in China on Essays at Yuhuage, Hunan Fine Arts Publishing House, Version of 2005.

[3] Zhang Weimin, Reports from North Suburb of Jinmen - experience of instructing farmers in fine arts creation on Fine Arts Research, 1987 (4).

[4] Pan Lusheng, Discussion on Modern Folk Paintings on Fine Arts Researches, 1990 (2). 